BEYOND THE SOUNDTRACK 
The publisher gratefully acknowledges the generous contribution to this book provided by the Ahmanson Foundation Humanities Endowment Fund of the University of California Press Foundation. 


\section{Beyond the Soundtrack}

Representing Music in Cinema

Edited by

DANIEL GOLDMARK

LAWRENCE KRAMER

RICHARD LEPPERT

\section{ㅁ}

UNIVERSITY OF CALIFORNIA PRESS

Berkeley Los Angeles London 
University of California Press, one of the most distinguished university presses in the United States, enriches lives around the world by advancing scholarship in the humanities, social sciences, and natural sciences. Its activities are supported by the UC Press Foundation and by philanthropic contributions from individuals and institutions. For more information, visit www.ucpress.edu.

University of California Press

Berkeley and Los Angeles, California

University of California Press, Ltd.

London, England

(C) 2007 by The Regents of the University of California

Chapter 8 is a version of the essay by Philip Brophy, "How Sound Floats on Land-The Suppression and Release of Folk and Indigenous Musics in the Cinematic Terrain," in Cinesonic: Film and the Sound of Music, edited by Philip Brophy (Sydney: AFTRS Publishing, 200o). Chapter 15 is a revised version of the essay by Krin Gabbard, "Miles from Home: Miles Davis and the Movies," The Source (University of Leeds)I (2004): 27-41.

\section{Library of Congress Cataloging-in-Publication Data}

Beyond the soundtrack : representing music in cinema / edited by Daniel Goldmark, Lawrence Kramer, Richard Leppert.

p. $\quad \mathrm{cm}$.

Includes bibliographical references (p. ), filmography (p. ), and index. ISBN 978-0-520-25069-7 (cloth : alk. paper) ISBN 978-0-520-25070-3 (pbk. : alk. paper)

1. Motion picture music-History and criticism. I. Goldmark, Daniel. II. Kramer, Lawrence, 1946- III. Leppert, Richard D.

ML2075.B475 2007

$781.5^{\prime} 42-\mathrm{dc} 22$

2006025494

Manufactured in the United States of America

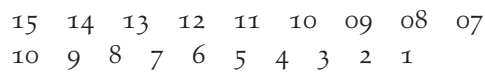

This book is printed on New Leaf EcoBook 50, a 100\% recycled fiber of which $50 \%$ is de-inked post-consumer waste, processed chlorine-free. EcoBook 50 is acid-free and meets the minimum requirements of ANSI/ASTM D5634-OI (Permanence of Paper). 